\title{
Assessment of Infection by Fusarium pseudograminearum in Wheat Seedling Tissues Using Quantitative PCR and a Visual Discoloration Scale
}

Noel L. Knight, Mark W. Sutherland, and Anke Martin, Centre for Systems Biology, Faculty of Sciences, University of Southern Queensland, Toowoomba, QLD, 4350, Australia; and Damian J. Herde, Department of Agriculture, Fisheries and Forestry Queensland (DAFFQ), Leslie Research Centre, Toowoomba, QLD, 4350, Australia

\begin{abstract}
Knight, N. L., Sutherland, M. W., Martin, A., and Herde, D. J. 2012. Assessment of infection by Fusarium pseudograminearum in wheat seedling tissues using quantitative PCR and a visual discoloration scale. Plant Dis. 96:1661-1669.

Assessment among cereal genotypes of relative seedling resistance to the crown rot pathogen Fusarium pseudograminearum has been primarily based on visual discoloration of the leaf sheaths. This study is the first to investigate the relationship between the widely used visual rating of seedling leaf sheath discoloration and the degree of colonization of these tissues by the pathogen, based on quantitative polymerase chain reaction (qPCR) of fungal DNA using primers specific for the translation elongation factor $\alpha$ sequence. Fourteen-day-old seedlings of four hard white spring wheat genotypes which differ in their degree of resistance to the pathogen, based on the expression of visible symptoms, were inoculated using a droplet method and assessed weekly from 7 to 35 days after inoculation (dai) for both discoloration and fungal DNA content per unit of tissue weight. Both visual assessment of disease symptoms and qPCR of fungal biomass indicated significant differences between the partially resistant and susceptible wheat genotypes from 14 dai. Visual discoloration of leaf

sheath tissues was strongly correlated with fungal biomass estimated by qPCR in all four genotypes; however, this correlation became weaker with increasing time after inoculation. Significant correlations between these parameters were indicated at 14, 21, and 28 dai whereas, by 35 dai, the correlation was not significant. Evaluation of plants at 14 dai provided a rapid test which gave clear discrimination between lines for both parameters and was the time point of closest correlation between fungal colonization and disease symptoms. Symptom expression at all times following inoculation was accompanied by tissue infection, and at no time was symptomless infection observed under this screening environment. These qPCR results confirm that visual assessments of disease symptoms reflect the extent of tissue colonization by the pathogen in recently colonized tissues and confirm the validity of visual assessments for disease rating in high-throughput screening of breeding materials.
\end{abstract}

Crown rot caused by Fusarium pseudograminearum O'Donnell $\& \mathrm{~T}$. Aoki $(=$ F. graminearum group I, = Gibberella coronicola $)$ is a serious disease of wheat (Triticum aestivum L.) worldwide $(4,31)$. It has been reported from all areas where wheat is grown, including Australia $(1,5)$, Europe $(2,6,28)$, North America (especially the Pacific Northwest; 8,23,32), South Africa (18,36), West Asia $(30,34)$, and North Africa $(15,21)$. Crown rot can be particularly damaging in Australia, resulting in an estimated \$79 million in lost yield per annum (24). Control of crown rot is principally based on management practices involving crop rotation to decrease field inoculum, especially where reduced tillage to conserve profile moisture results in carry-over of inoculum on stubble (4). Although commercial wheat cultivars with a low level of crown rot resistance are available to growers in some environments, the most promising sources of resistance identified to date are apparently quantitative in character $(3,7)$ and currently in unadapted backgrounds.

Improved crown rot resistance in cereal cultivars is a major aim of current breeding programs. Assessment of resistance has been based on initial phenotypic screening of seedlings, followed by screening of selected adult plants in the field in a range of environments. Historically, disease severity has been estimated by scoring the brown discoloration of either seedling leaf sheaths (LSs) or adult stem internodes and by recording the incidence of whiteheads $(12,27,39,40)$. More recently, some studies have varied the inoculation technique, scoring methodology, and sta-

Corresponding author: M. W. Sutherland,

E-mail: mark.sutherland@usq.edu.au

Accepted for publication 26 May 2012.

http://dx.doi.org/10.1094/PDIS-12-11-1050-RE

(C) 2012 The American Phytopathological Society tistical design for assessing discoloration in either seedlings $(19,22)$ or adult plants $(37)$.

There has been limited examination of the ability of visual tissue discoloration to accurately reflect the extent of colonization in genotypes of different resistance levels under similar environmental conditions. The degree to which tolerance mechanisms contribute to observed resistance is also unknown. The relationship between host plant discoloration and fungal biomass has direct implications for refining efficient screening methodologies that closely reflect disease impacts on grain yield and quality.

Quantitative polymerase chain reaction (qPCR) of fungal DNA has also been employed to estimate the extent of host colonization by a range of phytopathogenic fungi in cereals $(16,17,20,33)$. Hogg et al. (17) quantified DNA of several Fusarium spp., including $F$. pseudograminearum, during crown rot infections of adult plants in two red spring wheat cultivars and one durum cultivar, grown in infected field plots. They reported a positive correlation between Fusarium DNA content and disease severity scores for all three host genotypes in 2004 ( $r=$ approximately $0.77, P<0.001)$ but only the durum wheat in 2005 . However, qPCR analysis of $F$. pseudograminearum infection of wheat seedlings has not yet been reported.

The current study examines the relationship between the quantity of $F$. pseudograminearum biomass in host tissues, indicated by qPCR of fungal DNA, and the expression of disease symptoms by the host tissues. This examination was conducted in seedlings of four bread wheat genotypes of varying susceptibility at a range of time points following inoculation using a droplet inoculation method (22) and was made possible by the development of robust species-specific markers for $F$. pseudograminearum that could be assayed in the presence of multiplexed markers for host DNA. The relationship between $F$. pseudograminearum biomass and the visual discoloration of LSs was closely examined to determine the correlation between these two parameters and whether there is 
evidence of symptomless infection in some genotypes, indicated by growth of the fungus in tissues with an absence of visible disease responses.

\section{Materials and Methods}

Fungal strain and inoculum preparation. All experiments were performed using the highly aggressive $F$. pseudograminearum isolate A03\#24, collected from Tara, Queensland, Australia. A single conidial culture was grown and maintained on spezieller nährstoffarmer agar (25). Subcultures were grown on starch nitrate agar (11) in the dark at $25^{\circ} \mathrm{C}$ for 14 days. Conidia were collected by flooding plates with $5 \mathrm{ml}$ of a $6 \%$ Tween 20 solution before filtering through several layers of cheesecloth with high-purity water (MilliQ; Millipore), to a volume of $10 \mathrm{ml}$. The conidial suspension was quantified using a counting chamber (Weber and Sons) and diluted to a concentration of $10^{6}$ conidia $/ \mathrm{ml}$. The final suspension was stored for a maximum of 2 months at $-70^{\circ} \mathrm{C}$ before inoculation.

A selection of Fusarium spp. isolates collected during crown rot surveys, supplied by Phillip Davies, University of Sydney, and several $F$. pseudograminearum isolates from the Leslie Research Centre collection (Table 1) were grown on starch nitrate agar in the dark at $25^{\circ} \mathrm{C}$ for 14 days before DNA extraction and qPCR assessment.

Plant growth, inoculation, and disease assessment. Seed of $T$. aestivum (hard white spring wheat 'Janz', 'Puseas', 'EGA Wylie', 'EGA Gregory' and experimental line 2-49), T. turgidum durum ('Bellaroi'), and Hordeum vulgare ('Grimmett') were supplied by

Table 1. Fusarium and cereal species assessed using the Fusarium pseudograminearum and wheat primer/probe sets

\begin{tabular}{|c|c|c|c|}
\hline Species & $\begin{array}{c}\text { Number } \\
\text { tested }\end{array}$ & $\begin{array}{c}\text { F.pseudograminearum } \\
\text { primers }^{\mathrm{a}}\end{array}$ & $\begin{array}{l}\text { Wheat } \\
\text { primers }^{\mathrm{a}}\end{array}$ \\
\hline F. compactum ${ }^{\mathrm{b}}$ & 2 & - & - \\
\hline F. crookwellense $e^{\mathrm{b}}$ & 2 & - & - \\
\hline F. culmorum $^{\mathrm{b}}$ & 2 & - & - \\
\hline F. equiseti ${ }^{\mathrm{b}}$ & 2 & - & - \\
\hline$F$. poae $^{\mathrm{b}}$ & 2 & - & - \\
\hline F. proliferatum ${ }^{\mathrm{b}}$ & 2 & - & - \\
\hline F. scirpi ${ }^{\mathrm{b}}$ & 2 & - & - \\
\hline F. semitectum ${ }^{\mathrm{b}}$ & 2 & - & - \\
\hline F. pseudograminearum ${ }^{\mathrm{c}}$ & 8 & + & - \\
\hline F. graminearum $^{\mathrm{b}}$ & 5 & - & - \\
\hline Triticum aestivum $\mathrm{d}^{\mathrm{d}}$ & 5 & - & + \\
\hline T. turgidum durum ${ }^{\mathrm{d}}$ & 1 & - & + \\
\hline Hordeum vulgare ${ }^{\mathrm{d}}$ & 1 & - & - \\
\hline
\end{tabular}

a Symbols: + indicates a rise in fluorescence above the threshold cycle $(\mathrm{Ct})$ while - indicates that no rise in fluorescence above the Ct had occurred by cycle 35 for the primer/probe set. All genotypes within each species gave similar responses.

b Fusarium spp. collected during crown rot surveys, supplied by P. Davies, University of Sydney.

${ }^{c}$ F. pseudograminearum included five isolates supplied by P. Davies and three isolates from the Leslie Research Centre, DAFFQ collection.

${ }^{\mathrm{d}}$ Seed supplied by D. Herde, Leslie Research Centre, DAFFQ.
Damian Herde (Leslie Research Centre, Department of Agriculture, Fisheries and Forestry Queensland [DAFFQ]). DNA of each cereal genotype was used to assess the specificity of the qPCR assay (Table 1). A selection of four bread wheat genotypes demonstrating a range of resistance to crown rot-2-49 (partially resistant), EGA Wylie (moderately susceptible), EGA Gregory, (susceptible), and Puseas (highly susceptible)—was assessed for their individual reaction to crown rot disease. Seed were surface sterilized by rinsing for $2 \mathrm{~min}$ in a $2 \%$ sodium hypochlorite solution, followed by three rinses in high-purity water. Each seed was planted in a 5-by-5-by-10-cm pot, at a depth of $2.5 \mathrm{~cm}$ in Premium Hi-Retention commercial growing medium (Power Blend). All seedlings were grown in an environmentally controlled glasshouse at day and night temperatures of 24 and $15^{\circ} \mathrm{C}$, respectively, for 14 days.

Seedlings were inoculated 14 days after planting using a method modified from Mitter et al. (22). Potted seedlings were laid horizontally, each coleoptile was gently rubbed $0.5 \mathrm{~cm}$ behind the tip with a sterile toothpick, and then $6 \mu \mathrm{l}$ of the $10^{6}$ conidia $/ \mathrm{ml}$ inoculum was placed on this area. Control plants were treated with $6 \mu \mathrm{l}$ of high-purity water. After inoculation, seedlings were placed in a growth chamber in the dark for $48 \mathrm{~h}$ with two cycles of $25^{\circ} \mathrm{C}$ for $14 \mathrm{~h}$ followed by $15^{\circ} \mathrm{C}$ for $10 \mathrm{~h}$ at $100 \%$ relative humidity. After 48 $\mathrm{h}$, seedlings were placed upright in the growth chamber and subsequently maintained under the same temperature regime with $14 \mathrm{~h}$ of daylight at a photon flux density of $150 \mu \mathrm{mol} / \mathrm{m}^{2} / \mathrm{s}$. Plants were positioned in a randomized block design.

Harvest of LSs of all four genotypes was performed at 0, 1, 3, 5, $7,14,21,28$, and 35 days after inoculation (dai). Each time point was independently replicated and each replicate consisted of duplicate samples consisting of five plants. Separately harvested tissues included LSs 1 to 4 . The length of each LS was recorded. Separated, harvested tissues of five plants were placed into preweighed microfuge tubes.

At harvest, each of the collected tissues was rated based on the percentage of brown discoloration of the entire LS (39). Briefly, LSs were rated for disease on a 0 -to- 4 scale, where $0=$ no visible discoloration, $1=$ less than $25 \%$ discoloration, $2=25$ to $50 \%$ discoloration, $3=51$ to $75 \%$ discoloration and $4=$ greater than $75 \%$ discoloration. All LSs were stored at $-70^{\circ} \mathrm{C}$ until lyophilization.

DNA extraction. Lyophilized LSs were weighed and ground with a TissueLyser (Qiagen). Samples with dry weights greater than $0.01 \mathrm{~g}$ were subsampled into 0.005 - to 0.01 -g samples. Genomic DNA was extracted using a Qiagen DNeasy plant mini kit according to the manufacturer's recommended procedure. Samples were eluted into $200 \mu \mathrm{l}$ of Elution buffer and stored at $-4^{\circ} \mathrm{C}$ until required.

qPCR assay validation. $F$. pseudograminearum and wheat primer/probe sets were based upon GenBank sequences of translation elongation factor $\alpha$ and $\mathrm{g}$, respectively (Table 2). The $F$. pseudograminearum primers were modified from sequences supplied by D. Hartley (CSIRO). The remaining primers and probes were designed using Primer3 (29). Dual-labeled probes were ob-

Table 2. Primer/probe sets developed for quantification of Fusarium pseudograminearum DNA in extracts of wheat tissues using translation elongation factor (TEF) sequences

\begin{tabular}{|c|c|c|c|c|}
\hline Probe, primer ${ }^{\mathrm{a}}$ & Sequence $\left(5^{\prime} \rightarrow 3^{\prime}\right)$ & Target & Fragment (bp) & GenBank accession number \\
\hline \multicolumn{5}{|c|}{ F. pseudograminearum } \\
\hline TEF1 $\alpha .2 \mathrm{~F}$ & ATCATTCGAATCGCTCGACG & F. pseudograminearum & & $\ldots$ \\
\hline TEF1 $\alpha .2 \mathrm{R}$ & AAAAATTACGACAAAGCCGTAAAAA & F. pseudograminearum & 82 & \\
\hline TEF1 $\alpha .2 \mathrm{P}$ & ACTCGACACGCGCCTGTTACCC & F. pseudograminearum & $\ldots$ & DQ382162 \\
\hline \multicolumn{5}{|l|}{ Wheat } \\
\hline TEFG.5F & TCCGTGAAGGATTGAGGAA & Wheat & $\ldots$ & $\ldots$ \\
\hline TEFG.5R & GTCCTCTTCTAGAGTTCAAGTCACC & Wheat & 120 & $\ldots$ \\
\hline TEFG.5P & TGGCCCACGACTCCTGGAACCTATA & Wheat & $\ldots$ & DQ247872 \\
\hline
\end{tabular}

${ }^{\text {a }}$ Suffix: $\mathrm{F}=$ forward primer, $\mathrm{R}=$ reverse primer, and $\mathrm{P}=$ duel-labeled probes, where the $F$. pseudograminearum probe was labeled with reporter dye $\mathrm{CAL}$ Fluor Gold on the $5^{\prime}$ terminal and the wheat probe was labeled with reporter dye FAM on the $5^{\prime}$ terminal. Both probes were labeled with BHQ-1 on the $3^{\prime}$ terminal as the quencher. 
tained from Biosearch Technologies. Primer and probe sequences were assessed by a BLAST (www.ncbi.nlm.nih.gov/BLAST) search of the GenBank nucleic acid database using the Others database: Nucleotide Collection (nr/nt).

Primers were initially assessed in $25-\mu \mathrm{l}$ reactions $(0.5$ unit of Immolase DNA polymerase [Bioline], $100 \mu \mathrm{M}$ dNTPs, $1 \times \mathrm{Im}-$ mobuffer, $2.5 \mathrm{mM} \mathrm{MgCl} 2,0.25 \mathrm{mM}$ primers [Invitrogen], $2 \mu \mathrm{M}$ Syto9 nucleic acid stain [Invitrogen], and $5 \mu$ l of DNA template) using a Rotor-Gene 6000 (Corbett Life Sciences). Thermal cycling conditions were $95^{\circ} \mathrm{C}$ for $7 \mathrm{~min}$ followed by 40 cycles of $94^{\circ} \mathrm{C}$ for $30 \mathrm{~s}, 64^{\circ} \mathrm{C}$ for $30 \mathrm{~s}$, and $72^{\circ} \mathrm{C}$ for $30 \mathrm{~s}$. DNA amplicons were observed on a polyacrylamide gel using a Gel-Scan 2000 instrument (Corbett Life Sciences).

Dual-labeled probe PCR conditions. Reactions were performed in $20-\mu$ volumes containing autoclaved high-purity water, 0.5 units of Immolase DNA polymerase, $1 \times$ Immobuffer, $2.5 \mathrm{mM} \mathrm{MgCl}_{2} 100$ $\mu \mathrm{M}$ dNTPs, $150 \mathrm{nM}$ F. pseudograminearum CAL Fluor Goldlabeled probe, $150 \mathrm{nM}$ wheat FAM-labeled probe, $0.25 \mu \mathrm{M}$ forward and reverse primers for both organisms, and $5 \mu \mathrm{l}$ of DNA template.

Multiplex real-time qPCR was performed using clear $100-\mu 1$ strip tubes and caps (Corbett Life Sciences) in a Rotor-Gene 6000. Thermal cycling was completed in less than $2 \mathrm{~h}$ and conditions consisted of $10 \mathrm{~min}$ at $95^{\circ} \mathrm{C}$ and then 35 cycles of $95^{\circ} \mathrm{C}$ for $15 \mathrm{~s}$ and $64^{\circ} \mathrm{C}$ for $1 \mathrm{~min}$. The Rotor-Gene 6000 series software collected data for both reporter dyes every $0.15 \mathrm{~s}$ from each tube, generating a fluorescence profile for each amplification product. The threshold cycle $(\mathrm{Ct})$ was recorded for each dye as the cycle at which fluorescent signal, associated with an exponential growth of PCR product, exceeded background fluorescence.

PCR controls duplicated in every assay included no template controls (NTCs) and genomic DNA standards (positive or negative) for both $F$. pseudograminearum and wheat. Tenfold serial dilutions of pure genomic wheat DNA and pure genomic $F$. pseudograminearum DNA standards were initially tested in triplicate for assessment of the standard curve and PCR efficiencies. Each experimental PCR assay with unknown samples included standards run in duplicate. Each unknown sample was assayed at least once, with a random selection of samples duplicated across separate PCR assays. DNA concentrations of wheat and $F$. pseudograminearum standards were determined spectrophotometrically by measuring optical density at $260 \mathrm{~nm}$ using a nanophotometer (Implen). Standards were diluted into four 10-fold serial dilutions for $F$. pseudograminearum DNA (10 ng to $1 \mathrm{pg}$ ) and three 10-fold serial dilutions for wheat DNA (100 ng to 100 pg). Standard curves for both $F$. pseudograminearum and wheat were generated by linear regression analysis plotting known DNA amounts against the $\mathrm{Ct}$ calculated by the Rotor-Gene 6000 software V 1.7 in order to produce a regression equation. The slope (M) was calculated as being the change in $\mathrm{Ct}$ divided by the change in log input (DNA quantity). A $100 \%$ efficient amplification indicated a doubling of amplification product in each cycle, resulting in an $\mathrm{M}$ value of -3.322 , an amplification factor of 2 , and a reaction efficiency of 1 . The slope $(\mathrm{M})$ of the standard curve was used to determine the reaction efficiency (E) of the PCR: E = $\left[10^{(-1 / \mathrm{M})}\right]-1$. Optimal PCR efficiency was achieved when a slope of -3.32 was reached (Rotor-Gene 6000 software V 1.7). These results were reported as $y=\mathrm{M} x+B$, where $\mathrm{M}$ is the slope and $B$ the intercept.

Intra-assay variability was evaluated using 10 replicates of one DNA sample analyzed in a single qPCR assay. Inter-assay variability was evaluated using the same sample across 10 different qPCR assays.

qPCR normalization method. The wheat primer/probe set was designed to be included in the qPCR assay as an internal positive control and to enable normalization across samples. Normalization of samples served to adjust the $F$. pseudograminearum DNA estimates of colonization for differently sized tissue samples, pipetting accuracy, and sample-to-sample variation in both DNA extraction and PCR amplification efficiencies (41). Normalization of qPCR results was performed using two methods. After quantification, normalized estimates of $F$. pseudograminearum colonization of wheat tissue were obtained by dividing the quantity of $F$. pseudograminearum DNA by either the quantity of wheat DNA ( $F$. pseudograminearum DNA/wheat DNA, in nanograms) or the original extracted sample dry weight ( $F$. pseudograminearum DNA [in nanograms]/dry weight of wheat tissue [in milligrams]). Assessment of the consistency of host DNA quantities in LSs was also performed using control and infected LS 2 tissues from 7 to 35 dai across the four wheat genotypes.

Statistics. Comparisons between visual and qPCR ratings of individual genotypes were performed by analyzing arcsine squareroot-transformed values in a one-way analysis of variance and the multiple comparisons Tukey's honestly significant difference test in SPSS 17.0 (IBM). Homogeneity of variance was monitored using the Levene statistic. Weights and LS lengths of control and infected tissues were compared using a two-tailed paired sample $t$ test in SPSS 17.0. All tests used $\alpha=0.05$. Pearson correlation coefficients (two-tailed) were calculated in SPSS 17.0. The strength of each correlation was reported using the system described by Fowler et al. (14).

\section{Results}

qPCR assay development. Candidate primer pairs (Table 2) were tested individually and in multiplex reaction on $F$. pseudograminearum DNA, wheat DNA, or a combination of both. In addition, both primer/probe sets were assessed using DNA of a range of Fusarium and cereal species (Table 1). The F. pseudograminearum primer/probe set and wheat primer/probe set were compatible during multiplex qPCR assessment. Both sets required similar optimum PCR conditions, were specific to their target host (Table 1), amplified the expected sequences from their respective target DNA, and showed no interactions between primers. For detection purposes, a maximum of 35 cycles was deemed sufficient for standard curve production and was the cut-off to discriminate positive from negative samples, allowing for a rapid qPCR assay. $F$. pseudograminearum was quantifiable from 0.001 to $100 \mathrm{ng}$ and wheat was quantifiable from 0.05 to $500 \mathrm{ng}$. In singleplex and multiplex reactions, both primer/probe sets displayed high precision over a range of four orders of magnitude. The linear regression correlations between the $\mathrm{Ct}$ and known DNA quantities were high for both $F$. pseudograminearum $\left(R^{2}>0.99\right.$, $y=-3.5 x+26.8, \mathrm{E}=0.92)$ and wheat $\left(R^{2}>0.99, y=-3.3 x+30.0\right.$, $\mathrm{E}=0.99)$. The respective mean values $(n=10)$ and coefficient of variation $(\mathrm{CV})$ for the intra- and inter-assay variability of a single sample were $0.0164 F$. pseudograminearum DNA per wheat DNA (ng/ng) (CV percentage 4.8\%) and $0.0160 \mathrm{~F}$. pseudograminearum DNA per wheat DNA (ng/ng) (CV percentage 25.5\%) using 10 replicates.

qPCR normalization method. The $F$. pseudograminearum DNA per wheat DNA and $F$. pseudograminearum DNA per dry weight of extracted sample normalization methods gave similar results when comparing partially resistant and susceptible genotypes; however, at longer time periods after inoculation, the quantity of wheat DNA per milligram of tissue significantly decreased. A comparison between the wheat DNA present in control and infected LS 2 tissues of the same age demonstrated that wheat DNA content decreased in a similar manner from 0 to 35 dai as tissues began to visually senesce. Wheat DNA content was estimated using qPCR values obtained using the wheat primer/probe set (Table 2). Across the four genotypes, wheat DNA at 0 dai was 320 to 605 $\mathrm{ng} / \mathrm{mg}$ of LS tissue. The wheat DNA followed a similar linear decrease to 35 dai in both control and inoculated tissues, resulting in wheat DNA levels of 15 to $135 \mathrm{ng} / \mathrm{mg}$ of LS tissue. Visual assessment of DNA quality was performed using agarose gel electrophoresis and no differences in quality were observed between infected and uninfected tissues (data not shown). Due to the decrease in extracted wheat DNA in older tissues, fungal DNA yields were reported per unit of tissue dry weight.

Infection rating. Visual discoloration of LS 1 tissue was observed in some individual plants as early as 3 dai, although ratings within each genotype were quite variable between individual plants 
up to 7 dai. Visual ratings and qPCR values, predominantly of the younger LS 3 and LS 4 tissues, frequently indicated significant differences between genotypes from 14 dai (Fig. 1). qPCR values differentiated between the highly susceptible Puseas and the three other genotypes more frequently than visual ratings from 14 to 35 dai, with differences between qPCR values increasing from 14 to 28 dai. No disease symptoms were detected in control plants either visually or by qPCR.

Visual discoloration values differentiated between genotypes up to 28 dai; however, relative differences were less than at 14 dai, which was the most discriminating time to assess disease symptoms by this method. At 35 dai, visual rating could not discriminate between partially resistant and susceptible genotypes.

At all times post inoculation, excluding qPCR values at 28 dai, individual visual or qPCR values for LS 1 were not useful indica- tors of significant differences in colonization between genotypes (Fig. 1). The visual ratings of these tissues rapidly reached the maximum value, preventing any discrimination between genotypes, while qPCR only indicated a significant difference between genotypes at 28 dai.

The most consistent grouping of genotypes, in particular the significant separation of the partially resistant 2-49 from the susceptible Puseas, was achieved by using the mean visual scores or qPCR values $(n=4)$ of the sum of LS 1 to 4 , which indicated the extent of plant colonization (Fig. 2). Both the visual scores and qPCR values demonstrated similar trends in disease between all four genotypes.

For each sample replicate, the absolute qPCR values for LSs 1 to 4 were summed and normalized by dividing by the total dry weight of the combined LSs, and the mean of the four replicates was as-
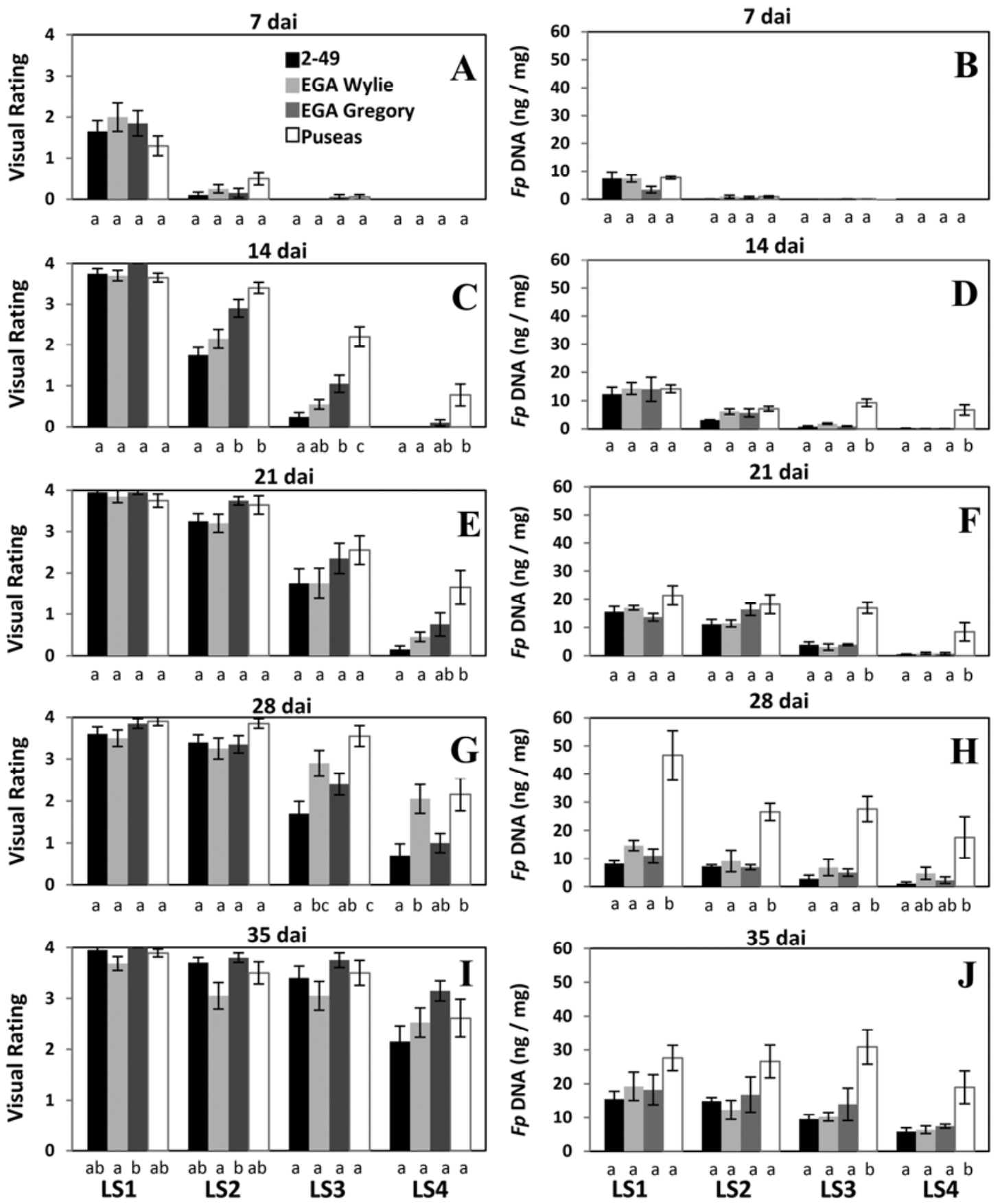

Fig. 1. Individual visual ratings due to crown rot disease and quantitative polymerase chain reaction (Fusarium pseudograminearum DNA [nanograms per milligram]) values of leaf sheath (LS) 1, LS 2, LS 3, and LS 4 at A and B, 7; C and D, 14; E and F, 21; G and H, 28; and I and J, 35 days after inoculation (dai). Columns represent the mean \pm standard error of four replicate samples of five plants. Different letters indicate significant differences $(P<0.05)$ between genotypes within respective leaf sheaths according to Tukey's honestly significant difference multiple comparison test. 
sessed over time. This showed an exponential increase in qPCR values from 7 to 35 dai, demonstrated by a linear relationship for the logarithm of the qPCR data over time for each cultivar (Fig. 3 ). The relative slope of the line ranked the cultivars from most to least susceptible, reflecting the predicted order of disease reaction.

Although 2-49 is considered to be more resistant than EGA Wylie and EGA Gregory, this was not reflected as a statistically significant difference in fungal DNA content. The mean values for 2-49, however, were predominantly the lowest among the four genotypes for each tissue across the times assessed (Figs. 1 and 2).

Correlations between visual rating and fungal DNA content. Due to the large spread in qPCR values, the logarithm of each qPCR value was used for comparison with visual ratings. The strength of the correlations was variable within genotypes and LSs, predominantly due to a small sample size of four and a narrow spread of values within genotypes (Table 3). Assessment of the ability of visual discoloration to indicate fungal biomass across genotypes was performed by analyzing correlations using data from all four genotypes. This allowed examination of the correlation between visual and qPCR values over a wide range of values. Combined genotype LS data indicated that discoloration of LS 1, which frequently exhibited a maximum visual rating, was only weakly correlated to fungal biomass, in contrast to the other LSs (Table 3). The spread of genotypes within the correlation was assessed at 14 dai (Fig. 4). By omitting the LS 1 values, which did not distinguish between genotypes (Fig. 1), and combining the values for LS 2, LS 3, and LS 4 for each of the four replicate samples, the spread of individual genotype values was demonstrated in conjunction with a strong correlation between visual scores and qPCR values at 14 dai (Fig. 4). Correlations generally appeared to be strongest in younger tissues undergoing initial disease development, becoming weaker as the extent of tissue invasion increased. Correlations between visual ratings and qPCR values of the four genotypes were not significant by 35 dai (Table 3 ).

Comparison of control and infected LS weights. Comparison of dry weights of control and infected LSs revealed that infected LSs were heavier than their control counterparts in all genotypes (Table 4). Significant increases in total weight were most frequent in LS 1 and LS 2. LS 5 in Puseas was the only tissue which recorded a weight significantly less than the control. The difference in weight between infected and uninfected tissues was established by 7 dai and only increased modestly in some genotypes at later time points (Table 4). The difference in weight was not due to variation in LS length during colonization (data not shown). Although a modest to strong correlation was observed between the estimated weight of $F$. pseudograminearum hyphae in infected tissue and the LS weight increase, the magnitude of the weight difference was much greater than that of the potential hyphal mass (Fig. 5). F. pseudograminearum weights were estimated from a standard curve comparing DNA yields from a range of weights of pure $F$. pseudograminearum mycelium. Furthermore, the weight difference between infected and uninfected LSs did not continue to increase at later harvest times, even though hyphae continued to proliferate (Table 4).

\section{Discussion}

The accurate quantification of a pathogen in diseased host tissue can be an important indicator of the degree of host susceptibility and is an essential component in assessing the extent of disease symptom expression relative to colonization. This study has developed a qPCR-based method specific for $F$. pseudograminearum DNA, whereas previous studies have employed primers specific only to the genus level (17). Compared with traditional quantitative methodologies, which rely on culturing the pathogen from infected tissues, qPCR is a more sensitive method, able to quantify pathogens in colonized tissues from very early to late stages of disease. The ability to compare traditional disease rating methods, particularly visual ratings, with qPCR measurements of fungal DNA provides insight into the relationship between symptom expression and the extent of fungal colonization in different host genotypes. In particular, these comparisons reveal whether individual genotypes exhibit symptomless infection by the pathogen such that, at a given level of pathogen spread, lower levels of disease symptoms are expressed, suggesting differences in disease expression between host genotypes.

Comparing genotypes for the extent of colonization of seedling LS tissues by $F$. pseudograminearum using visual rating and $\mathrm{qPCR}$ indicated significant differences between partially resistant and susceptible genotypes; however, the period over which differences between partially resistant and susceptible genotypes could be detected varied between rating methods. Although qPCR differentiated the degree of colonization between 2-49 and Puseas at

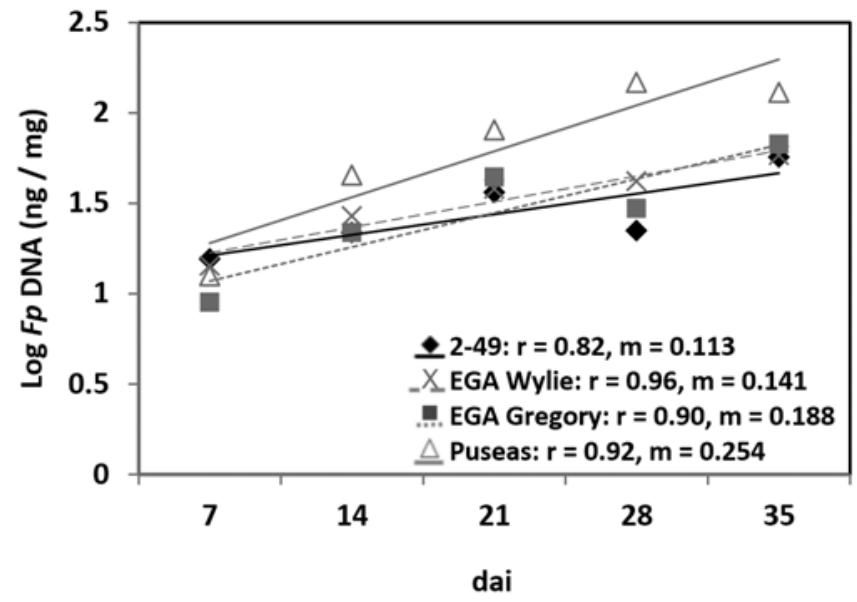

Fig. 3. Linear relationship between the logarithm of the total normalized Fusarium pseudograminearum DNA (nanograms per milligram) content per sample $(n=4)$ and time period (days after inoculation [dai]).
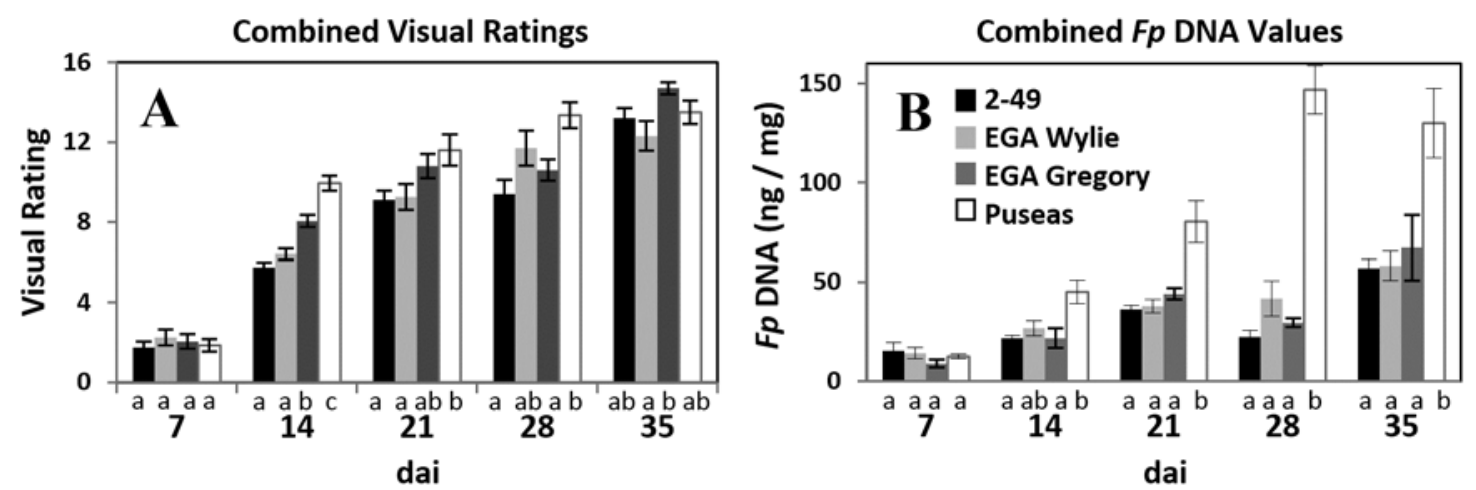

Fig. 2. Mean values ( $n=4)$ of the sum of leaf sheath $1,2,3$, and 4 for each host genotype's $\mathbf{A}$, visual ratings of crown rot disease and B, Fusarium pseudograminearum ( $F p$ ) DNA (nanograms per milligram) content from 7 to 35 days after inoculation (dai). Columns represent the mean \pm standard error of four replicate samples of five plants. Different letters indicate significant differences $(P<0.05)$ between genotypes within each time point. 
every time point measured from 14 to 35 dai, visual ratings could not distinguish differences between 2-49 and Puseas at 35 dai (Fig. 2 ). This difference in detection, and the reduced correlation over time between the two methods, may be partly due to the ordinal scale used by the visual rating, in which scores for individual LSs reach a maximum value of four, in comparison with the continuous logarithmic scale of the qPCR method. The observations also indicate that, even after maximum symptoms are expressed, the fungal biomass in host tissues may still increase, suggesting that, under the conditions of the seedling test, necrosis is an early response to fungal invasion. This is supported by the observation that visual symptoms vary most significantly between host genotypes at 14 dai whereas differences in pathogen DNA are most significant at 28 dai.

Further comparisons of the rating methods indicated that the strongest statistical correlation between visual rating of crown rot disease in seedling LS tissues and the logarithm of the qPCR data occurred at 14 dai in individual LS 2, 3, and 4 and the combined total of LS 1 to 4 values. The correlations generally weakened at later time points; however, visual ratings and $\mathrm{qPCR}$ values were significantly correlated up to 28 dai. There were no differences between host genotypes in the relationship between the extent of fungal DNA present and the expression of visible symptoms of disease. The strong correlations between tissue discoloration and fungal biomass also indicate that symptom development was not systemic and required the presence of the pathogen, an observation consistent with other evidence (26). Furthermore, no instances were observed where tissues displayed no discoloration but were infected by detectable quantities of fungal DNA, suggesting that there was no symptomless infection by the fungus in any of the genotypes examined under these experimental conditions.

Symptom development and colonization of seedling LS tissues over time indicated differences between genotypes. In the period up to 7 dai, the degree of variation in initial infection between individual plants within genotypes obscured any differences between genotypes. This probably reflected initial differences in the rate of penetration of individual seedlings. However, by 14 dai, significant differences in symptom expression and the quantity of fungal DNA became apparent. From this time onward, differences between genotypes were most obvious in the younger LSs whereas, in the older tissues, differences were less pronounced. It is interesting to note that EGA Wylie and EGA Gregory, considered to be moderately susceptible and susceptible, respectively, in the field, were not significantly different from 2-49 at any time point, demonstrating the difficulty of differentiating moderately resistant from moderately susceptible genotypes in seedling assays.

In contrast to Stephens et al. (33), where three phases of infection by $F$. graminearum were reported in wheat seedling tissues, the current study did not detect corresponding phases of infection

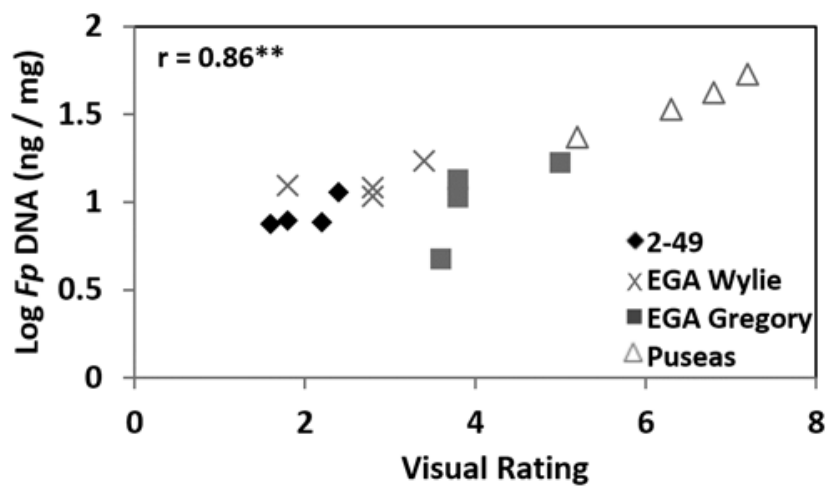

Fig. 4. Relationship in four wheat genotypes between the mean of the sum of leaf sheath 2, 3, and 4 visual ratings of crown rot disease and the logarithm of Fusarium pseudograminearum ( $F p)$ DNA (nanograms per milligram) content in the three leaf sheaths at 14 days after inoculation. Each point represents a single replicate (five plants); ${ }^{* *}$ indicates that Pearson correlation coefficient $(r)$ is significant at the 0.01 level (two-tailed).

Table 3. Pearson's correlation coefficients ( $r$ ) for leaf sheath (LS) 1, 2, 3, and 4 separately, as an aggregate for each genotype, and as combined genotype values, comparing visual ratings of crown rot disease and the logarithm of quantitative polymerase chain reaction values (Fusarium pseudograminearum DNA, nanograms per milligram) values from 7 to 35 days after inoculation (dai) across four genotypes ${ }^{\mathrm{a}}$

\begin{tabular}{|c|c|c|c|c|c|}
\hline \multirow[b]{2}{*}{ Time (dai), tissue } & \multicolumn{5}{|c|}{ Pearson's $r$} \\
\hline & $2-49$ & EGA Wylie & EGA Gregory & Puseas & Combined \\
\hline \multicolumn{6}{|l|}{7} \\
\hline LS 1 & 0.72 & 0.52 & $0.96^{*}$ & 0.08 & 0.46 \\
\hline LS 2 & -0.36 & 0.59 & 0.53 & $0.98^{*}$ & $0.68 * *$ \\
\hline LS 3 & & & -0.67 & -0.34 & 0.17 \\
\hline Aggregate & 0.67 & 0.64 & $0.96^{*}$ & 0.65 & $0.58^{*}$ \\
\hline \multicolumn{6}{|l|}{14} \\
\hline LS 1 & -0.55 & 0.8 & - & 0.93 & -0.08 \\
\hline LS 2 & 0.53 & 0.71 & 0.79 & 0.60 & $0.66 * *$ \\
\hline LS 3 & 0.86 & -0.42 & 0.86 & 0.64 & $0.79 * *$ \\
\hline LS 4 & $\ldots$ & $\ldots$ & -0.58 & 0.57 & $0.93 * *$ \\
\hline Aggregate & -0.73 & 0.09 & 0.71 & $0.98^{*}$ & $0.67 *$ \\
\hline \multicolumn{6}{|l|}{21} \\
\hline LS 1 & 0.75 & 0.88 & -0.89 & -0.05 & -0.14 \\
\hline LS 2 & -0.27 & 0.78 & 0.50 & -0.78 & 0.37 \\
\hline LS 3 & 0.86 & 0.79 & 0.21 & -0.69 & 0.46 \\
\hline LS 4 & 0.25 & 0.75 & 0.97 & -0.60 & $0.57 *$ \\
\hline Aggregate & -0.53 & 0.83 & 0.06 & 0.91 & $0.59^{*}$ \\
\hline \multicolumn{6}{|l|}{28} \\
\hline LS 1 & $0.96^{*}$ & -0.94 & -0.27 & -0.84 & 0.15 \\
\hline LS 2 & -0.44 & 0.79 & 0.01 & -0.71 & 0.49 \\
\hline LS 3 & 0.82 & $0.99 *$ & 0.59 & $0.96 *$ & $0.87 * *$ \\
\hline LS 4 & 0.93 & 0.88 & 0.76 & $0.99 * *$ & $0.86 * *$ \\
\hline Aggregate & 0.83 & 0.94 & 0.60 & 0.35 & $0.73^{* *}$ \\
\hline \multicolumn{6}{|l|}{35} \\
\hline LS 1 & 0.57 & 0.91 & $\ldots$ & -0.30 & 0.15 \\
\hline LS 2 & -0.78 & 0.54 & 0.58 & 0.34 & 0.35 \\
\hline LS 3 & -0.33 & -0.54 & -0.42 & 0.75 & 0.00 \\
\hline LS 4 & 0.95 & 0.67 & 0.54 & 0.10 & 0.41 \\
\hline Aggregate & -0.05 & 0.81 & -0.26 & 0.53 & 0.23 \\
\hline
\end{tabular}

a Genotypes $n=4$; combined $n=16$; * and ** indicate correlation is significant at the 0.05 and 0.01 level (two-tailed), respectively. 
by F. pseudograminearum (Fig. 2). Instead, a log-linear increase in F. pseudograminearum DNA was observed from 1 to 28 dai. Although this pattern of growth was observed in all host genotypes, the rate of increase was less in the partially resistant genotype 2-49 compared with the most susceptible genotype Puseas (Fig. 3), indicating a slower rate of colonization. This is supported by colonization data for individual LSs, with 2-49 showing less colonization in younger tissues than Puseas. This effect has been reported in other studies $(26,27)$.
In further contrast to $F$. graminearum infections (33), in which crown rot symptoms develop slowly, usually taking 4 to 8 weeks to become visible, the current study observed discoloration of LS tissue under $F$. pseudograminearum-inoculated coleoptiles from 3 dai. Readily observable discoloration of at least three LSs was present on seedlings at 7 dai, with significant observable differences between genotypes at 14 dai. This contrast is almost certainly due to the differing pathogenicities of $F$. pseudograminearum and $F$. graminearum, the latter of which is a major cause of

Table 4. Absolute (in milligrams [mg]) and relative (\%) weight difference between Fusarium pseudograminearum-infected and uninfected control leaf sheaths (LSs) from 7 to 35 days after inoculation (dai) for 2-49, EGA Wylie, EGA Gregory, and Puseas ${ }^{\mathrm{a}}$

\begin{tabular}{|c|c|c|c|c|c|c|c|c|c|c|}
\hline \multirow[b]{2}{*}{ Genotype } & \multicolumn{2}{|c|}{7 dai } & \multicolumn{2}{|c|}{14 dai } & \multicolumn{2}{|c|}{21 dai } & \multicolumn{2}{|c|}{28 dai } & \multicolumn{2}{|c|}{35 dai } \\
\hline & mg & $\%$ & mg & $\%$ & mg & $\%$ & mg & $\%$ & mg & $\%$ \\
\hline \multicolumn{11}{|l|}{$2-49$} \\
\hline LS 1 & $3.9^{*}$ & 39 & $5.4 *$ & 50 & 8.9 & 76 & 3.8 & 32 & $7.3^{*}$ & 54 \\
\hline LS 2 & $4.5^{*}$ & 45 & $5.4^{*}$ & 43 & $10.5^{*}$ & 64 & 6.5 & 45 & 10.2 & 56 \\
\hline LS 3 & 0.8 & 38 & 2.8 & 14 & 0.6 & 2 & 4.4 & 20 & 1.9 & 5 \\
\hline LS 4 & $\ldots$ & $\ldots$ & 2.0 & 23 & -6.5 & -13 & -0.2 & -1 & -4.0 & -6 \\
\hline LS 5 & $\ldots$ & $\ldots$ & $\ldots$ & $\ldots$ & $\ldots$ & $\ldots$ & -1.3 & -4 & -2.0 & -2 \\
\hline \multicolumn{11}{|l|}{ EGA Wylie } \\
\hline LS 1 & 2.4 & 26 & $2.7 *$ & 27 & 1.6 & 15 & 2.2 & 23 & 4.1 & 45 \\
\hline LS 2 & $1.5^{*}$ & 11 & 4.3 & 29 & 2.9 & 16 & $6.7^{*}$ & 43 & 6.4 & 44 \\
\hline LS 3 & 2.1 & 20 & 2.3 & 14 & 5.1 & 22 & $6.4 *$ & 35 & 4.7 & 22 \\
\hline LS 4 & $\ldots$ & $\ldots$ & 1.6 & 8 & 0.2 & 1 & 8.4 & 29 & 3.7 & 11 \\
\hline LS 5 & $\ldots$ & $\ldots$ & $\ldots$ & $\ldots$ & $\ldots$ & $\ldots$ & 1.6 & 3 & 11.0 & 24 \\
\hline \multicolumn{11}{|c|}{ EGA Gregory } \\
\hline LS 1 & $1.6^{*}$ & 12 & $3.1^{*}$ & 22 & $4.0 *$ & 31 & 1.5 & 14 & $8.1 *$ & 80 \\
\hline LS 2 & 0.8 & 4 & $7.9 *$ & 41 & $8.6^{*}$ & 48 & 4.9 & 31 & $12.1 *$ & 74 \\
\hline LS 3 & 0.2 & 1 & $5.3^{*}$ & 23 & 5.4 & 18 & 3.5 & 16 & 6.3 & 23 \\
\hline LS 4 & $\ldots$ & $\ldots$ & 1.3 & 5 & 0.9 & 2 & -0.4 & -1 & 9.4 & 20 \\
\hline LS 5 & $\ldots$ & $\ldots$ & $\ldots$ & $\ldots$ & $\ldots$ & $\ldots$ & -2.5 & -5 & 14.3 & 23 \\
\hline \multicolumn{11}{|l|}{ Puseas } \\
\hline LS 1 & 4.3 & 24 & 2.7 & 15 & $7.2^{*}$ & 49 & 1.7 & 8 & 6.7 & 35 \\
\hline LS 2 & $7.3^{*}$ & 24 & 7.8 & 28 & 12.2 & 54 & 5.4 & 17 & 12.2 & 45 \\
\hline LS 3 & 3.4 & 14 & 3.7 & 10 & 8.0 & 20 & 6.5 & 18 & 10.1 & 25 \\
\hline LS 4 & $\ldots$ & $\ldots$ & -12.1 & -24 & -13.1 & -20 & -5.7 & -11 & 6.9 & 10 \\
\hline LS 5 & $\ldots$ & $\ldots$ & $\ldots$ & $\ldots$ & $\ldots$ & $\ldots$ & $-18.7 *$ & -28 & -10.8 & -13 \\
\hline
\end{tabular}

${ }^{a}$ An asterisk $(*)$ indicates significantly different absolute values from the control tissues. Significant differences $(P<0.05)$ were assessed using a two-tailed paired sample $t$ test; $n=4$, with each of the samples consisting of five LSs.
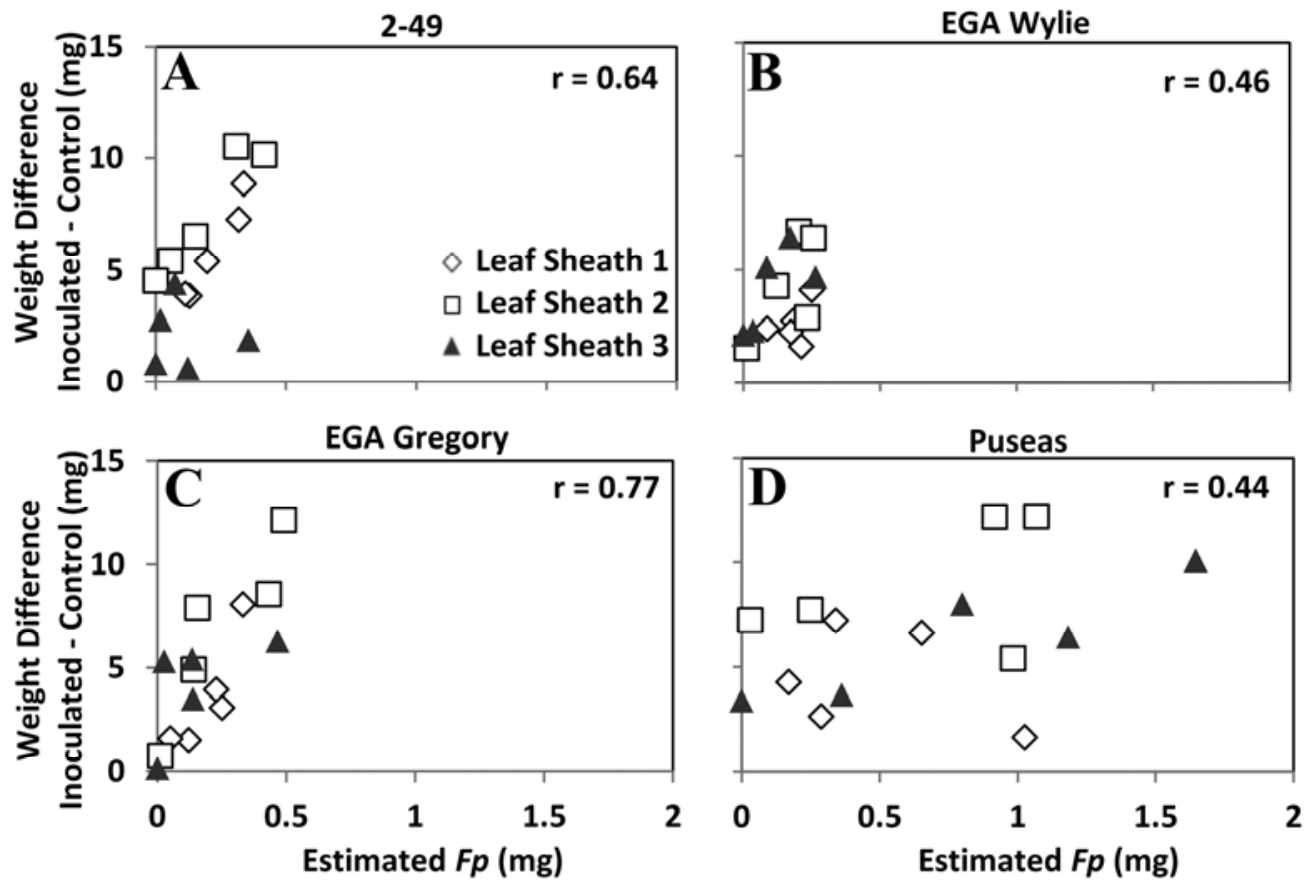

Fig. 5. Relationship of the weight difference occurring between Fusarium pseudograminearum ( $F p$ )-infected tissues and control tissues to the estimated weight of $F$. pseudograminearum mycelium in A, 2-49; B, EGA Wylie; C, EGA Gregory; and D, Puseas at 7 to 35 days after inoculation across leaf sheaths 1, 2, and 3. F. pseudograminearum weights were estimated from a standard curve comparing DNA yields from a range of weights of pure $F$. pseudograminearum mycelium; $r=$ Pearson's correlation coefficient. 
head blight in wheat but is isolated only infrequently from wheat tissues expressing symptoms of crown rot in the field $(1,32)$.

The relationship between visual discoloration and the extent of fungal colonization has had limited examination elsewhere. Percy et al. (26) performed isolation counts on $F$. pseudograminearuminfected cereal tissues by placing LS tissues on Czapek Dox Agar and counting the colonies formed after 1 week. They reported that correlations between visual disease ratings and reisolation counts of the pathogen from infected tissues were highly significant $(r=$ approximately 0.8 ), with younger, less-diseased tissues demonstrating the strongest relationship, observations consistent with this study. In a study of adult plants, Hogg et al. (17) evaluated stem internodes visually for crown rot severity and using qPCR specific for the Fusarium trichodiene synthase gene. Visual disease and Fusarium spp. content were positively correlated with each other across three host genotypes in a 2004 trial ( $r=$ approximately 0.77 , $P<0.001)$. They further analyzed relationships between crown rot infection and grain yield, reporting that yields for two spring wheat genotypes were negatively correlated with Fusarium spp. DNA content in 2004. These results highlight the potential value of qPCR as a tool in further field-based studies, which will be greatly assisted by the $F$. pseudograminearum-specific primer/probe set developed in this current study.

The increase in the dry weights of infected LS tissues compared with uninfected controls was an unexpected observation (Table 4) and was ubiquitous in infected LS 1, LS 2, and LS 3. The decrease in weight of the younger LSs, such as LS 5 in Puseas, was possibly due to stunting or delayed development in response to intense disease challenge. The significant increases in the weight of infected tissues occurred by 7 dai in all four host genotypes examined, suggesting an early, nonspecific reaction to infection. The mechanism and physiology behind this reaction remains unknown. Desmond et al. (9) have detected induction of the peroxidase TaPERO by $F$. pseudograminearum in infected wheat plants. This enzyme may have a role in cell wall modification, particularly lignin deposition (38). Biochemical tests for an increase in structural components frequently implicated in disease responses such as lignin (35), cellulose (10), and silicon (13) may illuminate the nature of this increase in inoculated host LS weight.

This study has demonstrated that visual assessment of crown rot symptoms on LSs using a 0-to-4 scale generally reflects the extent of fungal colonization, particularly in recently infected younger tissues, in a manner similar to the absolute $F$. pseudograminearum biomass values generated using qPCR. This finding supports the current role of visual assessment in initial screening of large numbers of lines to detect sources of crown rot resistance for deployment into breeding programs. At the present time, the use of qPCR in this context is time consuming and expensive relative to visual rating; however, $\mathrm{qPCR}$ analysis provides a precise tool for more focused investigations, including the comparison of lines that have been selected in initial screens and the analysis of bi-parental mapping populations to identify quantitative trait loci linked to crown rot resistance genes. Furthermore, the application of qPCR to describe $F$. pseudograminearum infection and colonization under varying nutrient and stress conditions will aid in better understanding genotype-environment interactions during disease development.

\section{Acknowledgments}

Financial support for this project was provided by the Grains Research and Development Corporation. N. Knight acknowledges the support of an Australian Postgraduate Award.

\section{Literature Cited}

1. Backhouse, D., Abubakar, A. A., Burgess, L. W., Dennis, J. I., Hollaway, G. J., Wildermuth, G. B., Wallwork, H., and Henry, F. J. 2004. Survey of Fusarium species associated with crown rot of wheat and barley in eastern Australia. Australas. Plant Pathol. 33:255-261.

2. Balmas, V. 1994. Root rot of wheat in Italy caused by Fusarium graminearum group 1. Plant Dis. 78:317.

3. Bovill, W. D., Ma, W., Ritter, K., Collard, B. C. Y., Davis, M., Wildermuth, G. B., and Sutherland, M. W. 2006. Identification of novel QTL for re- sistance to crown rot in the doubled haploid wheat population 'W21MMT70' × 'Mendos'. Plant Breed. 125:538-543.

4. Burgess, L. W., Backhouse, D., Summerell, B. A., and Swan, L. J. 2001 Crown rot of wheat. Pages 271-294 in: Fusarium: Paul E. Nelson Memorial Symposium. B. Summerell, J. Leslie, D. Backhouse, W. Bryden, and L. Burgess, eds. American Phytopathological Society, St. Paul, MN.

5. Burgess, L. W., Wearing, A. H., and Toussoun, T. A. 1975. Surveys of Fusaria associated with crown rot of wheat in eastern Australia. Aust. J. Agric. Res. 26:791-799.

6. Cassini, R. 1981. Fusarium diseases of wheat and corn in western Europe. Pages 56-63 in: Fusarium: Diseases, Biology, and Taxonomy. P. E. Nelson, T. A. Toussoun, and R. J. Cook, eds. The Pennsylvania State University Press, University Park.

7. Collard, B. C. Y., Grams, R. A., Bovill, W. D., Percy, C. D., Jolley, R., Lehmensiek, A., Wildermuth, G., and Sutherland, M. W. 2005. Development of molecular markers for crown rot resistance in wheat: mapping of QTLs for seedling resistance in a '2-49' \& 'Janz' population. Plant Breed. 124:532537.

8. Cook, R. J. 1968. Fusarium root and foot rot of cereals in the Pacific northwest. Phytopathology 58:127-131.

9. Desmond, O. J., Edgar, C. I., Manners, J. M., Maclean, D. J., Schenk, P. M., and Kazan, K. 2006. Methyl jasmonate induced gene expression in wheat delays symptom development by the crown rot pathogen Fusarium pseudograminearum. Physiol. Mol. Plant Pathol. 67:171-179.

10. Dickson, J. G., Eckerson, S. H., and Link, K. P. 1923. The nature of resistance to seedling blight of cereals. Proc. Natl. Acad. Sci. USA 9:434-439.

11. Dodman, R. L., and Reinke, J. R. 1982. A selective medium for determining the population of viable conidia of Cochliobolus sativus in soil. Aust. J. Agric. Res. 33:287-291.

12. Dodman, R. L., and Wildermuth, G. B. 1987. Inoculation methods for assessing resistance in wheat to crown rot caused by Fusarium graminearum group 1. Aust. J. Agric. Res. 38:473-486.

13. Fauteux, F., Rémus-Borel, W., Menzies, J. G., and Bélanger, R. R. 2005. Silicon and plant disease resistance against pathogenic fungi. FEMS Microbiol. Lett. 249:1-6.

14. Fowler, J., Cohen, L., and Jarvis, P. 1998. Practical Statistics for Field Biology. John Wiley and Sons, Chichester, UK.

15. Gargouri, S., Hajlaoui, M. R., Guermech, A., and Marrakchi, M. 2001. Identification des espèces fongiques associées à la pourriture du pied du blé et étude de leur répartition selon les étages bioclimatiques en Tunisie. EPPO Bull. 31:499-503.

16. Guo, J.-R., Schnieder, F., and Verreet, J.-A. 2006. Presymptomatic and quantitative detection of Mycosphaerella graminicola development in wheat using a real-time PCR assay. FEMS Microbiol. Lett. 262:223-229.

17. Hogg, A. C., Johnston, R. H., and Dyer, A. T. 2007. Applying real-time quantitative PCR to Fusarium crown rot of wheat. Plant Dis. 91:1021-1028.

18. Klaasen, J., Matthee, F., Marasas, W., and Van Schalkwyk, D. 1991 Comparative isolation of Fusarium species from plant debris in soil and wheat stubble and crowns at different locations in the southern and western Cape. Phytophylactica 23:299-307.

19. Li, X., Liu, C., Chakraborty, S., Manners, J. M., and Kazan, K. 2008. A simple method for the assessment of crown rot disease severity in wheat seedlings inoculated with Fusarium pseudograminearum. J. Phytopathol. 156:751-754.

20. Melloy, P., Hollaway, G., Luck, J. O., Norton, R. O. B., Aitken, E., and Chakraborty, S. 2010. Production and fitness of Fusarium pseudograminearum inoculum at elevated carbon dioxide in FACE. GCB Bioenergy 16:3363-3373.

21. Mergoum, M., Braun, H. J., Nicol, J., Bagci, A., Ekiz, H., Aktas, H. Dusunceli, F., Cetin, L., Ketata, H., Yahyaoui, A., Bolat, N., and Keser, M. 2000. Screening wheat for root rot disease in WANA region. Page 186 in: Proc. 6th Int. Wheat Congr. Budapest.

22. Mitter, V., Zhang, M. C., Liu, C. J., Ghosh, R., Ghosh, M., and Chakraborty, S. 2006. A high-throughput glasshouse bioassay to detect crown rot resistance in wheat germplasm. Plant Pathol. 55:433-441.

23. Moya-Elizondo, E. A., Rew, L. J., Jacobsen, B. J., Hogg, A. C., and Dyer, A. T. 2011. Distribution and prevalence of Fusarium crown rot and common root rot pathogens of wheat in Montana. Plant Dis. 95:1099-1108.

24. Murray, G. M., and Brennan, J. P. 2009. Estimating disease losses to the Australian wheat industry. Australas. Plant Pathol. 38:558-570.

25. Nirenberg, H. I. 1976. Untersuchungen über die morphologische Differenzierung in der Fusarium Sektion Liseola. Mitt. Biol. Bundesanst. Land Forstwirtsch. Berlin-Dahlem 169:1-117.

26. Percy, C. D., Wildemuth, G. B., and Sutherland, M. W. Symptom development proceeds at different rates in susceptible and partially resistant cereal seedlings infected with Fusarium pseudograminearum. Australas. Plant Pathol. DOI 10.1007/s13313-012-0146-2

27. Purss, G. S. 1966. Studies of varietal resistance to crown rot of wheat caused by Fusarium graminearum Schw. Queensl. J. Agric. Anim. Sci. 23:475-498.

28. Rossi, V., Cervi, C., Chiusa, G., and Languasco, L. 1995. Fungi associated with foot rots on winter wheat in northwest Italy. J. Phytopathol. 143:115119.

29. Rozen, S., and Skaletsky, H. J. 2000. Primer3 on the WWW for general 
users and for biologist programmers. Pages 365-386 in: Bioinformatics Methods and Protocols: Methods in Molecular Biology. K. S and M. S, eds. Humana Press, Totowa, NJ.

30. Saremi, H., Ammarellou, A., and Jafary, H. 2007. Incidence of crown rot of wheat caused by Fusarium pseudograminearum as a new soil born fungal species in north west Iran. Pak. J. Biol. Sci. 10:3606-3612.

31. Smiley, R. W., Gourlie, J. A., Easley, S. A., Patterson, L.-M., and Whittaker, R. G. 2005. Crop damage estimates for crown rot of wheat and barley in the Pacific northwest. Plant Dis. 89:595-604.

32. Smiley, R. W., and Patterson, L. 1996. Pathogenic fungi associated with Fusarium foot rot of winter wheat on the semiarid Pacific northwest. Plant Dis. 80:944-949.

33. Stephens, A. E., Gardiner, D. M., White, R. G., Munn, A. L., and Manners, J. M. 2008. Phases of infection and gene expression of Fusarium graminearum during crown rot disease of wheat. Mol. Plant-Microbe Interact. 21:1571-1581

34. Tunali, B., Nicol, J. M., Hodson, D., Uçkun, Z., Büyük, O., Erdurmuş, D., Hekimhan, H., Aktaș, H., Akbudak, M. A., and Bağc1, S. A. 2008. Root and crown rot fungi associated with spring, facultative, and winter wheat in Turkey. Plant Dis. 92:1299-1306.
35. Vance, C. P., Kirk, T. K., and Sherwood, R. T. 1980. Lignification as a mechanism of disease resistance. Annu. Rev. Phytopathol. 18:259-288.

36. Van Wyk, P., Los, O., Pauer, G., and Marasas, W. 1987. Geographic distribution and pathogenicity of Fusarium species associated with crown rot of wheat in the Orange Free State, South Africa. Phytophylactica 19:271-274.

37. Wallwork, H., Butt, M., Cheong, J. P. E., and Williams, K. J. 2004. Resistance to crown rot in wheat identified through an improved method for screening adult plants. Australas. Plant Pathol. 33:1-7.

38. Whetten, R. W., MacKay, J. J., and Sederoff, R. R. 1998. Recent advances in understanding lignin biosynthesis. Annu. Rev. Plant Physiol. Plant Mol. Biol. 49:585-609.

39. Wildermuth, G. B., and McNamara, R. B. 1994. Testing wheat seedlings for resistance to crown rot caused by Fusarium graminearum group 1. Plant Dis. 78:949-953.

40. Wildermuth, G. B., McNamara, R. B., and Quick, J. S. 2001. Crown depth and susceptibility to crown rot in wheat. Euphytica 122:397-405.

41. Winton, L. M., Stone, J. K., Watrud, L. S., and Hansen, E. M. 2002. Simultaneous one-tube quantification of host and pathogen DNA with realtime polymerase chain reaction. Phytopathology 92:112-116. 